\title{
Integrating Camelina Into Organic Pig Production - Impact on Growth Performance of Pigs, Costs, and Returns
}

\author{
Yuzhi Z. Li ${ }^{1,2 *}$, W. F. Lazarus ${ }^{3}$, C. Reese ${ }^{1}$, A. M. Hilbrands ${ }^{1}$, R. B. Cox ${ }^{2}$, F. Forcella ${ }^{4}$, \\ R. W. Gesch ${ }^{4}$ and L. J. Johnston ${ }^{1,2}$ \\ 1 West Central Research and Outreach Center, University of Minnesota, Morris, MN, United States, ${ }^{2}$ Department of Animal \\ Science, University of Minnesota, St. Paul, MN, United States, ${ }^{3}$ Department of Applied Economics, University of Minnesota, \\ St. Paul, MN, United States, ${ }^{4}$ North Central Soil Conservation Research Lab, Agriculture Research Service (ARS), \\ United States Department of Agriculture (USDA), Morris, MN, United States
}

OPEN ACCESS

Edited by:

Xue Li,

Agriculture and Agri-Food Canada (AAFC), Canada

Reviewed by:

Ahmet Yavuz Pekel, Istanbul University Cerrahpasa, Turkey

Luigi Pari,

Council for Agricultural and Economics Research (CREA), Italy

${ }^{*}$ Correspondence:

Yuzhi Z. Li

yuzhili@umn.edu

Specialty section:

This article was submitted to Agroecology and Ecosystem Services, a section of the journal

Frontiers in Sustainable Food Systems

Received: 24 August 2021 Accepted: 30 November 2021 Published: 20 December 2021

Citation:

Li YZ, Lazarus WF, Reese C, Hilbrands AM, Cox RB, Forcella $F$ Gesch RW and Johnston LJ (2021) Integrating Camelina Into Organic Pig Production-Impact on Growth Performance of Pigs, Costs, and
The sustainability of organic production and cover crops depends on production costs and the economic value of products. Feed cost, contributing $65-75 \%$ of the total production cost, has a significant impact on profitability of organic pig farming. Utilizing grains harvested from cover crops as a feed ingredient for organic pigs can potentially protect the environment and increase the economic value of cover crops. This study was the first to evaluate the viability of integrating winter cover crop, camelina, into organic pig production. Winter camelina was grown organically in single or relay with soybeans to increase the total yield per hectare. Camelina yields in monocrop and in relay-crop fields were 1,394 and $684 \mathrm{~kg} \mathrm{ha}^{-1}$, respectively. Although the total yield of camelina and soybean $\left(1,894 \mathrm{~kg} \mathrm{ha}^{-1}\right)$ in the relay-crop field was higher than camelina yield in the monocrop field, monocropping camelina is more economical than relay-planting with soybeans due to the difference in production costs. Camelina press-cake was supplemented in diets fed to pigs raised under near-organic standards. Supplementing 10\% camelina press-cake in diets reduced feed intake, weight gain, final weight at market, carcass weight, and dressing percent of pigs, but did not affect feed efficiency, belly firmness or pork quality. The viability of integrating camelina into organic pig production depends on marketing organic pigs for $\$ 2.4 \mathrm{~kg}^{-1}$ of live weight and marketing camelina oil for $\$ 3.59 \mathrm{~kg}^{-1}$ or more if monocropping.

Keywords: camelina, organic pigs, costs and returns, cover crops, organic agriculture

\section{INTRODUCTION}

Organic agriculture is a fast-growing segment in the United States. By 2019, 2.2 million hectares of farmland, accounting for $0.5 \%$ of total farmland, were certified for organic production (USDA, 2020). Organic agricultural commodity sales increased by $30 \%$ between 2016 and 2019 , reaching an all-time high of $\$ 9.9$ billion in 2019 . However, organic pig production is small compared with other organic commodities. Only 166 of the 16,585 certified organic farms nationwide in 2019 were pig farms. About 26,000 $(26,179)$ organic pigs were sold, accounting for $0.02 \%$ of total marketed pigs across the United States in 2019. Compared to European Union countries where 5\% of farmland is managed organically and $0.5 \%$ of total pigs are raised organically (Fruh et al., 2014), there is potential to expand organic pig production in the United States. 
Pigs rely on high energy and high protein diets to achieve their genetic potential for efficient growth performance. Traditional feed ingredients that contain high energy and protein for pigs are corn and soybean meal. The price of organic corn and soybean meal has been 2-3 times that of conventional corn and soybean meal over the last 5 years in the United States (AMS, 2020). Since feed cost can contribute $65-75 \%$ of the total cost of producing an organic pig (Larson et al., 2002, 2003), feed cost has a significant impact on profitability of organic pig farming. As a result, organic pig farmers are looking for alternative feed ingredients to reduce feed costs.

Grains harvested from winter cover crops may be a sustainable and viable alternative to organic corn and soybean meal because adding winter cover crops to organic crop rotations can provide soil health benefits such as reducing soil erosion, and controlling weeds and crop pests (Bowles et al., 2020; Pirvan et al., 2020). One winter cover crop with potential as an alternative protein and energy source for pigs in the Midwestern United States is camelina [Camelina sativa (L.) Crantz]. Camelina is an oilseed crop that can be planted on marginal land due to its hardiness, resistance to diseases and insects, and tolerance to drought (Berti et al., 2016). Camelina is a fast-growing annual plant. Winter camelina (cv. "Joelle") is sown in mid to late September and harvested for oilseed in late June or early July in the Midwest (Gesch and Cermak, 2011). Camelina can be relay-cropped with soybean (that is soybean can be sown into standing camelina in the spring) to potentially increase the total oilseed yield (Gesch et al., 2014). Winter camelina does not winter kill, and covers the land in early spring to prevent soil erosion (Weyers et al., 2021). Winter camelina can suppress early summer weeds and sequester available soil nitrate in spring when most soil nitrate enters groundwater, tile lines, streams, and lakes (Gesch and Cermak, 2011; Ott et al., 2019; Weyers et al., 2019; Hoerning et al., 2020). Consequently, camelina can reduce potential water pollution caused by corn-soybean rotations in the Midwest. Because camelina requires minimal inputs of water, fertilizer, and pesticide (Fan and Eskin, 2013; Gesch and Johnson, 2015), it has great potential for organic production. Camelina seed can be used to produce edible oil or biofuel (Zubr, 1997; Waraich et al., 2013; Puzio et al., 2021). The by-product of camelina oil production, camelina press-cake (CPC) can be used as an alternative protein and energy source for organic pigs (Woyengo et al., 2018). Thus, integration of camelina into organic pig production can potentially protect the environment, generate revenue from camelina oil, and reduce feed cost by using CPC for organic pig production.

Camelina seed contains about $35-40 \%$ oil, and $30-40 \%$ of total fatty acids are alpha-linolenic acid (an essential omega- 3 fatty acid), which has benefits for cardiovascular health in humans (Zubr, 1997; Waraich et al., 2013). Consumption of camelina oil can help prevent coronary heart disease, neurological problems, poor growth, arrhythmias, and thrombosis, in addition to enhancing regeneration of cells and skin elasticity in humans (Vollmann et al., 1996; Waraich et al., 2013). The inclusion of camelina oil in animal feed can increase plasma omega-3 fatty acids and reduce serum triglyceride concentrations in pigs (NÍ Eidhin et al., 2003).
Camelina press-cake contains about $35 \%$ crude protein, $14 \%$ oil, $10 \%$ crude fiber, and 5\% ash (Almeida et al., 2013). The standardized ileal digestibility (SID) of crude protein and amino acids in CPC is mostly comparable with that of canola meal for pigs (Almeida et al., 2013). The digestible and metabolizable energy in CPC is higher than that in soybean meal and canola meal (Kahindi et al., 2014; Liu et al., 2016). However, CPC contains high concentrations of antinutritional compounds, such as glucosinolates and trypsin inhibitors (Lee et al., 2017; Amyot et al., 2019). High levels of glucosinolates are toxic to pigs and can increase metabolic burden on the liver resulting in enlarged livers (Tripathi and Mishra, 2007). In addition, glucosinolates taste bitter to pigs and can reduce feed intake (Meadus et al., 2014; Smit and Beltranena, 2017).

While winter camelina has good potential for organic production, no research has been conducted to evaluate the viability of integrating camelina into an organic pig production system. Growing camelina organically in the Midwest and feeding diets supplemented with CPC to organic pigs have not been documented. Thus, objectives of the current study were to: (1) evaluate effects of replacing corn and soybean meal with $\mathrm{CPC}$ on growth performance and pork quality of organic pigs, and (2) calculate the costs and returns for including camelina in a crop rotation and a pig feeding trial. We hypothesized that replacing corn and soybean meal with CPC would not negatively impact growth performance and pork quality of pigs, and that integrating camelina into organic pig production would be a viable economical option for farmers.

\section{MATERIALS AND METHODS}

This project was conducted at the West Central Research and Outreach Center (WCROC), University of Minnesota located in Morris, Minnesota of the United States, from 2018 through 2020.

\section{Organic Camelina Production}

Eight hectares of land that is certified for organic production at the WCROC were used for organic winter camelina production between 2018 and 2019. Four hectares were used as a monocrop (camelina only) field and the remaining 4 ha were used as a relaycrop (camelina relayed with soybean) field. Winter camelina (var. "Joelle") was seeded using a grain seed drill on Oct 1st, 2018, after harvesting corn for silage in both the mono and relay crop fields. The camelina sowing time was later than desired (midSeptember; Gesch et al., 2014) due to rain and wet fields, which prevented proper functioning of the seed drill. Row spacing was $15 \mathrm{~cm}$ for the camelina in the monocrop field, with a seeding rate of $8 \mathrm{~kg} \mathrm{ha}^{-1}$. In the relay-crop field, camelina was seeded the same way except that a row was skipped every $76 \mathrm{~cm}$ as described by Gesch et al. (2014). The skip-rows were designed for relay inter-seeding soybean the following spring. The seeding rate of camelina in the relay-crop field was $6 \mathrm{~kg} \mathrm{ha}^{-1}$. Camelina germinated 17 days after seeding and emerged before the first snowfall. During the planting and growing phase, the crop was managed organically in both fields. No herbicides or pesticides were applied. 
On June 3, 2019, before the camelina flowered, organically certified soybeans were seeded at 445,000 seeds $\mathrm{ha}^{-1}$ in the skip-rows in the relay-crop field. Camelina in both the monoand relay-crop field was harvested on July 13, 2019. At harvest, soybeans in the relay cropped field were in the 4-leaf stage, still small enough so as not to be damaged by harvesting the camelina. Harvesting camelina seed was performed with a standard combine with sieves and screens adjusted to the setting for canola due to the small size of camelina seed. During harvest, camelina was cut about $20 \mathrm{~cm}$ above the ground in the monocrop field and about $30 \mathrm{~cm}$ above the ground in the relaycrop field to avoid cutting the soybeans. At harvest, camelina seeds were sampled and measured for moisture content by drying the samples at $60^{\circ} \mathrm{C}$ for $48 \mathrm{~h}$. The seeds then were air-dried and stored according to the Organic Production Protocol of the WCROC, which was developed based on the National Organic Standards [National Organic Program (NOP), 2020].

\section{Quality Test of Camelina Seed, Oil, and Press-Cake}

Camelina seeds were cold-pressed (at room temperature) for oil at a commercial organic oil processing plant (Healthy Oilseeds, Carrington, North Dakota). Camelina seeds and CPC were sampled and analyzed for concentration of moisture, crude protein, crude fat, crude fiber, neutral detergent fiber (NDF), total calcium, phosphorus, and minerals (iron, sodium, potassium, magnesium, manganese, copper, and zinc) at a commercial lab (Midwest Laboratories, Omaha, Nebraska), and for amino acid profiles at the Experiment Station Chemical Laboratories (University of Missouri, Columbia, Missouri). Additionally, camelina oil, seeds, and CPC were analyzed for anti-nutritional compounds (glucosinolates and trypsin inhibitors) at BioProfile Testing Labs (St. Paul, MN). Fatty acid profiles of camelina seed, oil, and CPC were quantified at the same lab as amino acids. The CPC produced was used as a feed ingredient for pigs in the feeding trial described below.

\section{Supplementing Camelina Press-Cake in Diets for Organic Pigs}

A feeding trial was conducted between 2019 and 2020 to evaluate the impact of including dietary CPC on growth performance of pigs, pork quality, and costs and returns of organic pig production. The experimental protocol used in the study was reviewed and approved by the University of Minnesota Institutional Animal Care and Use Committee (IACUC\#: 200638189A).

\section{Experimental Design and Management of Pigs}

A randomized complete block design was employed using four blocks. Each block consisted of 100 growing-finishing pigs housed in a straw-bedded hoop barn. One hoop barn housed a group of control pigs and a group of treatment pigs' side-by-side in two pens. Two hoop barns were used twice, with a total of 400 pigs involved over a period of 14 months for the study. All pigs were managed according to the National Organic Standards [National Organic Program (NOP), 2020], except without access to outdoor environments.
Pigs in the control group were fed corn and soybean meal (SBM) basal diets (control diets), and pigs in the treatment group were fed diets supplemented with 10\% CPC (treatment diets). The supplemented CPC replaced corn and SBM in the control diets on an as-fed basis. The corn and SBM were certified for organic production. Four phases of control and treatment diets were formulated and fed to pigs based on their body weights (Table 1) during the study period. All diets were formulated to meet or exceed nutrient requirements of pigs recommended by the National Research Council (NRC) (2012). The study period started when pigs first received experimental diets (control or treatment diet) at 10 weeks of age and ended when average weight of pigs reached about $120 \mathrm{~kg}$ at 24 weeks of age.

Within each block, pigs born to 16 sows were used. The 16 sows in each block farrowed in two bedded, group-farrowing rooms within a week, with eight sows in each room. All piglets were castrated within the first week after birth. Tail docking and teeth clipping were not performed. Pigs were weaned at 5 weeks of age by removing the sows from the farrowing rooms. After weaning, pigs remained in each bedded farrowing room as a large group and were provided an organically-certified complete nursery diet (Riverside Feeds, Riceville, IA). Pigs remained in the farrowing rooms for another 3 weeks after weaning.

At 8 weeks of age, 100 healthy pigs with no visual signs of illness, lameness or any other physical injuries were selected and weighed. Pigs were transferred to two pens (a control pen and a treatment pen) in a growing-finishing hoop barn, with equal number of pigs balanced for sex and body weight in each pen $\left(50\right.$ pigs pen $\left.{ }^{-1}\right)$. Each pen $(6 \mathrm{~m} \times 24 \mathrm{~m})$ was equipped with a round bulk feeder with 12 feeding spaces and a water fountain with four drinking spaces. Pigs were allowed 2 weeks to adapt to the new environment before receiving treatment diets. During the 2-week adaptation period, pigs were fed the same diet as previously offered in farrowing rooms. At 10 weeks of age, pigs were offered their experimental diets (Control or CPC) until the end of the experiment when pigs reached market weight (about $120 \mathrm{~kg}$ ). Feeders, drinkers, and animal health were monitored daily. The barns were ventilated naturally through openings on the sides and ends of the barn with no mechanical ventilation, heating, or cooling systems. Thermal environment in the barns was maintained by adjusting the openings of the barn and the amount of bedding provided. Wheat straw was used as bedding throughout the study. The depth of straw bedding was maintained at 40 to $60 \mathrm{~cm}$ during winter months, 10 to $30 \mathrm{~cm}$ during summer months, and 20 to $40 \mathrm{~cm}$ during other months. Hoop barns were cleaned between each block of pigs and fresh bedding added when pigs entered the barns. Throughout the study period, fresh bedding was added as needed to maintain clean and dry lying areas, and to maintain the desired microthermal environment for the pigs.

\section{Data Collection}

Feed Intake, Weight Gain, and Gain Efficiency

Pigs were weighed individually every 4 weeks during the study period. All feed deliveries to each pen were weighed and recorded. Remaining feed in the feeder on weigh days was weighed to allow calculation of feed disappearance on a pen basis. 
TABLE 1 | Concentration of ingredients in experimental diets (as-fed basis).

\begin{tabular}{|c|c|c|c|c|c|c|c|c|}
\hline \multirow[b]{2}{*}{ Item } & \multicolumn{2}{|c|}{ Phase 1 (22-50 kg BWa $)$} & \multicolumn{2}{|c|}{ Phase 2 (50-68 kg BWa) } & \multicolumn{2}{|c|}{ Phase 3 (68-86 kg BWa) } & \multicolumn{2}{|c|}{ Phase $4\left(86 \mathrm{~kg}\right.$ to market $\left.\mathrm{BW}^{\mathrm{a}}\right)$} \\
\hline & Control & $10 \% \mathrm{CPC}^{\mathrm{b}}$ & Control & $10 \% \mathrm{CPC}$ & Control & $10 \% \mathrm{CPC}$ & Control & $10 \% \mathrm{CPC}$ \\
\hline \multicolumn{9}{|l|}{ Ingredient, \% } \\
\hline Organic corn & 60.49 & 54.86 & 66.24 & 60.56 & 70.62 & 64.94 & 75.87 & 70.20 \\
\hline Organic soybean meal & 36.91 & 32.74 & 31.21 & 27.04 & 26.83 & 22.66 & 21.58 & 17.40 \\
\hline Camelina press-cake & 0 & 10.00 & 0 & 10.00 & 0 & 10.00 & 0 & 10.00 \\
\hline Mineral-vitamin basemix ${ }^{c}$ & 2.40 & 2.40 & 2.40 & 2.40 & 2.40 & 2.40 & 2.40 & 2.40 \\
\hline Monocalcium phosphate & 0.20 & 0 & 0.15 & 0 & 0.15 & 0 & 0.15 & 0 \\
\hline Total & 100.00 & 100.00 & 100.00 & 100.00 & 100.00 & 100.00 & 100.00 & 100.00 \\
\hline
\end{tabular}

a Body weight.

${ }^{b}$ Camelina press-cake.

${ }^{c}$ Riverside Farmix Plain for organic pigs, Riverside Feeds LLC, Riceville, IA.

From these data, average daily gain (ADG), average daily feed intake (ADFI), and gain to feed (G:F) were calculated.

\section{Morbidity and Mortality}

For pigs that were removed or that died, date of removal or death and reasons for removal or death were recorded. For sick or injured pigs that needed medical treatment, a treatment plan was developed under the supervision of a designated veterinarian. All treatments were recorded.

\section{Carcass Traits}

At the end of the study, all pigs, except 16 pigs from each treatment group reserved for pork quality evaluation (see section Pork Quality Evaluation), that reached the minimum weight $(104 \mathrm{~kg})$ for market were shipped to a commercial meat processing plant for harvest. At the meat processing plant, hot carcass weight and backfat thickness at the last rib were measured and recorded. Dressing percentage was calculated as (hot carcass weight/liveweight) $\times 100 \%$ [National Pork Producer Council (NPPC), 2000]. Fat-free lean content of the carcass was determined according to the National Pork Producer Council (NPPC), 2000 equation using hot carcass weight and last rib backfat depth.

\section{Pork Quality Evaluation}

For the third and fourth blocks, eight gilts from each treatment group with body weight close to their mean pen weight were transported $260 \mathrm{~km}$ to the Meat Science Laboratory on St. Paul campus for harvest and pork quality evaluation. Pigs were harvested according to approved standard operating procedures for humane slaughter, which included electrical stunning followed by exsanguination (Harris et al., 2017). Final body weight was recorded before electrical stunning. Following evisceration, livers were retrieved and weighed with the gall bladder removed. Carcass traits, belly firmness, and pork quality were evaluated using methods described by Zhu et al. (2021). Hot carcass weight and carcass length (from the forward edge of the first rib to the aitch bone) were recorded. Midline backfat thickness was measured opposite the first, 10th, and last ribs, and at the last lumbar vertebra. Loin eye muscle (Longissimus thoracis) area was measured at the 10 th rib by tracing the outline of the area on acetate tracing paper. Retrieved bellies were placed on a flat surface, and belly length and thickness were measured. Data of belly thickness were the averages of belly thickness measured at anterior ventral, posterior ventral, anterior dorsal, and posterior dorsal locations. Belly firmness was evaluated by belly hang angle (Whitney et al., 2006). Bellies were placed on a sharp edge of a triangular stainless steel smokehouse stick with the skin-side down. Hang angle was the upper angle of the isosceles triangle created by hanging the belly over the smokehouse stick. The distance between the cranial and caudal ends of the suspended belly was measured as hang distance. Belly hang angle was calculated with belly length and hang distance using the equation: Belly hang angle (degree) $=\cos ^{-1}[(0.5 \times$ belly length ${ }^{2}-$ hang distance $\left.{ }^{2}\right) /\left(0.5 \times\right.$ belly length $\left.\left.^{2}\right)\right]$ (Schieck et al., 2010; Villela et al., 2017). Pork $\mathrm{pH}$ at $45 \mathrm{~min}$ and $24 \mathrm{~h}$ postmortem was determined using a $\mathrm{pH}$ meter (Testo model 205, Sparta, NJ) inserted in the biceps femoris muscle in the ham of each carcass. Shear force was measured to evaluate tenderness of pork chops using a texture analyzer (Shimadzu Universal Tester EZ-SX; Kyoto, Japan) fitted with a Warner-Bratzler Shear Force (WBSF) attachment. Drip loss, purge loss, and cook loss were measured to evaluate water holding capacity of pork chops. Subjective color (from Score $1=$ pale pinkish gray to Score $6=$ Dark purplish red, with Score $3=$ reddish pink being desired) and marbling score (from Score $1=1 \%$ intramuscular fat to Score $6=6 \%$ intramuscular fat) was evaluated in loin eye muscle (pork chops) at the 10th rib [National Pork Producer Council (NPPC), 2000].

\section{Economic Analysis}

The market for camelina seed, oil, and CPC is not currently well-established to provide reliable estimates of future market prices. In the absence of reliable estimates of future market prices, the economical feasibility of growing winter camelina and feeding CPC to pigs was evaluated by calculating a set of minimum required sale prices and maximum allowable purchase prices for camelina seed, CPC, and oil that would be required to make an organic crop rotation and pig feeding enterprise with camelina as economically feasible as similar ones that do not include camelina. 
TABLE 2 | Machinery sizes and per-hectare costs used for calculation of costs to grow camelina.

\begin{tabular}{lc}
\hline Machinery sizes & Costs, $\mathbf{h a}^{-1}$ \\
\hline Chisel Plow, 11.3 m & $\$ 34$ \\
Field cultivator, 18.2 m & $\$ 31$ \\
Presswheel drill, 9.1 m & $\$ 36$ \\
Combine flex platform, 7.6 m & $\$ 96$ \\
Grain cart & $\$ 37$ \\
Non-machinery labor (for marketing, etc.) & $\$ 12$ \\
Total machinery and labor & $\$ 246$ \\
\hline
\end{tabular}

A typical crop rotation with small grains in the Midwest is a 3-year rotation of corn grain-spring wheat-soybeans. In the economic analysis, camelina was considered a cover crop and the camelina production follows wheat production. This is because some or all organic producers seeded cover crops after organic wheat between 2017 and 2019 [University of Minnesota Center for Farm Financial Management (CFFM), 2021]. The economic analysis is organized in a partial budgeting format (Boehlje and Eidman, 1984) which looks at the differences in costs and returns compared with such a typical three-crop rotation that does not include camelina. In the relay-planting scenario, soybeans are planted after camelina in the third year of the typical rotation. In the monocrop camelina scenario, the camelina replaces the soybeans in the third year. Thus, the soybean growing cost is incurred in the relay-planting scenario but is avoided in the monocrop scenario. Another minor cost savings in the camelina scenarios compared with the University of Minnesota Center for Farm Financial Management (CFFM) (2021) summaries is the elimination of the cover crop expense following the wheat that the organic wheat enterprises in the University of Minnesota Center for Farm Financial Management (CFFM) (2021) summary incurred on average. In the analysis, replacing those existing cover crops with camelina would result in a savings that offsets some of the camelina growing cost.

The calculation of a crop producer's minimum required sale price for camelina seed draws on several data sources. The camelina seed cost, camelina yield, and the soybean yield reduction of the following relay-planted soybean crop were from the current study. The soybean yield reduction was compared with average organic soybean yield between 2017 and 2019 in the Midwest [University of Minnesota Center for Farm Financial Management (CFFM), 2021]. The average organic soybean yield was $2,268 \mathrm{~kg} \mathrm{ha}^{-1}$ with growing costs of $\$ 630 \mathrm{ha}^{-1}$ in the University of Minnesota Center for Farm Financial Management (CFFM) (2021) summary. The machinery costs per hectare were based on types and sizes typical of a commercial crop operation (Lazarus, 2020), which were based on prices of new machinery purchased in 2020 as listed in Table 2.

The minimum required camelina sale price from the crop budget was converted to a per-kg of CPC basis based on the percentage of CPC in camelina seed in the current study. It was then compared with the maximum price that a hypothetical pig producer would be willing to pay for CPC to make pig feeding as profitable as feeding a non-camelina diet. Feed cost per pig was calculated based on average growth performance of pigs in each treatment group, and cost of feed ingredients used for the current study, with CPC replacing organic corn grain and soybean meal in the treatment diets. Organic corn grain was valued at $\$ 0.35 \mathrm{~kg}^{-1}$, soybean meal at $\$ 0.88 \mathrm{~kg}^{-1}$, and base mix at $\$ 1.23 \mathrm{~kg}^{-1}$ based on market conditions in west-central Minnesota in 2020. Given that camelina oil is a co-product of $\mathrm{CPC}$, the difference between the minimum sale and maximum purchase prices of CPC is assumed to be made up by marketing the oil. A minimum required sale price for the oil was calculated as the residual from the calculations. Economical feasibility of the whole system hinges on whether it would be possible to market the camelina oil at a sale price at or above that minimum required oil sale price.

\section{Data Analyses}

Data collected from the feeding trial were analyzed using SAS software (Version, 9.4; SAS Institute Inc., Cary, NC). The Glimmix procedure with the Gaussian regression model was used for analysis of continuous variables (growth performance, hot carcass weight, dressing and lean percentage, backfat thickness, liver weight, carcass length, loin eye muscle area, belly thickness and hang angle, pork post-mortem $\mathrm{pH}$, water holding capacity, and shear force value), and the Poisson regression model for analyses of count data (subjective color and marbling score of pork chops). All models included dietary treatment as a fixed effect, with pen serving as a random effect and the experimental unit. For data collected over time, repeated measures statistical models were used that included week and interaction between treatment and week as fixed effects. Initial body weight at 10 weeks of age was used as a covariate for analyses of final body weight and hot carcass weight. Final body weight was used as a covariate for the analysis of dressing percentage. Hot carcass weight was used as a covariate for analyses of backfat thickness and loin eye muscle area (Zhu et al., 2021). Morbidity and mortality data were combined due to low incidence and analyzed using the Frequency procedure with chisquare analysis. Both belly hang angle and adjusted belly hang angle with belly thickness as a covariate were analyzed (Schieck et al., 2010). All tests were two-tailed tests. Differences were considered significant when $P \leq 0.05$, and trends when $0.05<$ $P \leq 0.10$.

\section{RESULTS}

\section{Camelina Yield, and Quality of Camelina Seeds, Oil, and Press-Cake}

At harvest, camelina yield was $1,575 \mathrm{~kg} \mathrm{ha}^{-1}$ and $772 \mathrm{~kg} \mathrm{ha}^{-1}$ in the monocrop and relay-crop field, respectively, both with $25 \%$ moisture content. After drying, moisture content dropped to $14 \%$. Camelina yield with $14 \%$ moisture content was $1,394 \mathrm{~kg}$ $\mathrm{ha}^{-1}$ in the monocrop field, and $684 \mathrm{~kg} \mathrm{ha}^{-1}$ in the relay crop field.

Camelina seeds contained $34.6 \%$ crude fat (oil) on an asis basis (Table 3). Camelina press-cake contained $34.4 \%$ crude protein and $9.3 \%$ crude fat, suggesting that CPC can be a useful 
TABLE 3 | Analyzed nutrients and amino acid profiles of camelina seed, press-cake, organic corn, and soybean meal (SBM).

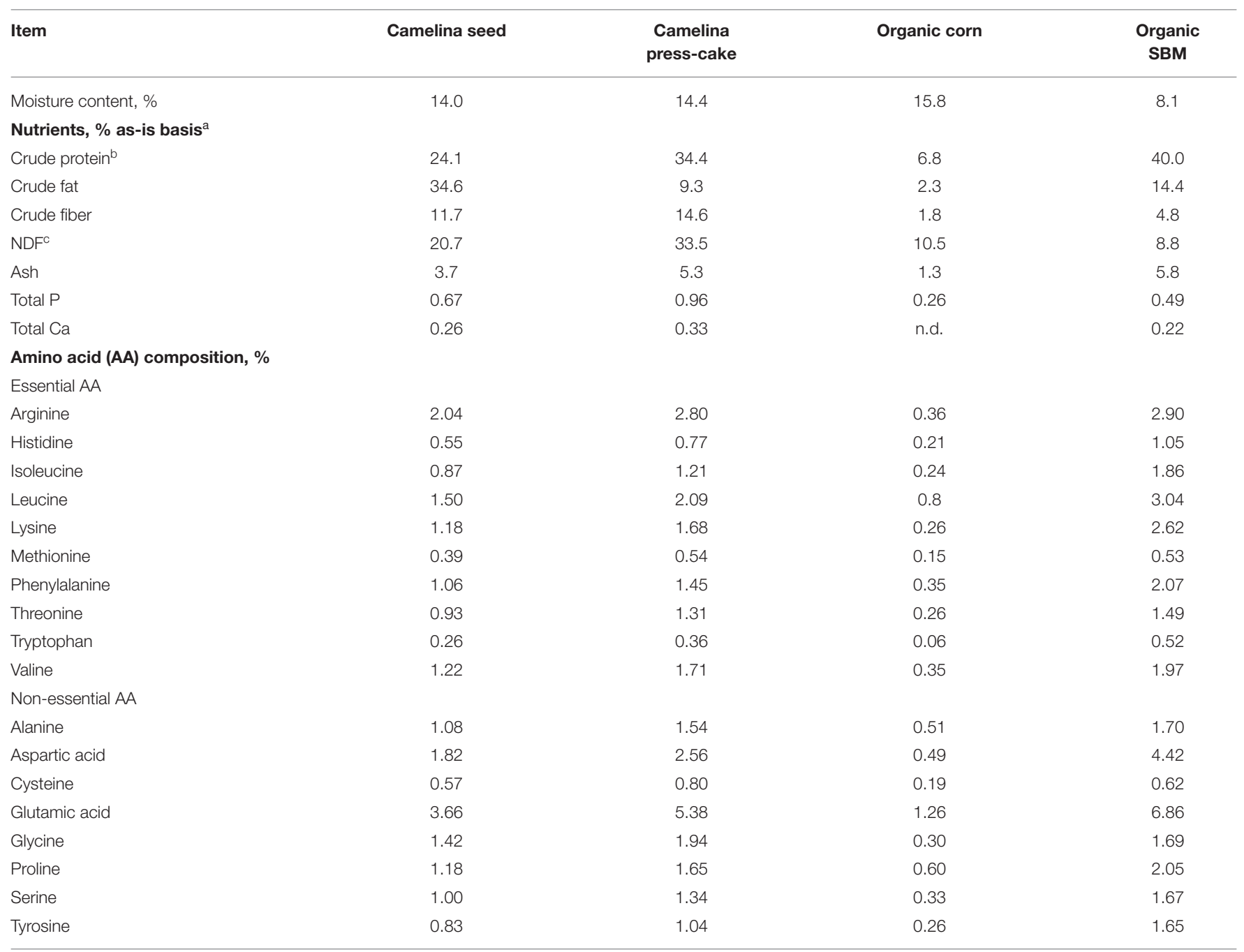

${ }^{a} \mathrm{~W} / \mathrm{W} \%=$ grams per 100 grams of samples.

${ }^{b}$ Crude protein $=N(\%) \times 6.25$.

${ }^{c}$ Neutral detergent fiber.

protein and energy source for livestock feed. However, compared to corn and SBM, CPC had higher concentration of NDF, which may negatively affect digestibility of a diet supplemented with CPC. Concentrations of crude protein and amino acids, especially essential amino acids, in CPC were lower compared to those in SBM. Particularly, concentration of lysine, the first limiting amino acid for pigs, in CPC accounted for only $64 \%$ of lysine in SBM.

Total saturated fatty acids (SFA) in camelina oil, seeds, and CPC were lower compared to SFA in corn and SBM (Table 4). But, camelina oil, seeds, and CPC had higher concentrations of monounsaturated fatty acids (MUFA) compared to corn and SBM. One of the MUFA in camelina was erucic, which potentially can reduce palatability of camelina for pigs (Meadus et al., 2014). Erucic concentrations in camelina oil, seeds and $\mathrm{CPC}$ in the current study ranged from 2.3 to $2.4 \%$ of total fatty acids which is typical for winter camelina (Matthaus and Zubr, 2000; Walia et al., 2021). While the total PUFA concentrations in camelina oil, seeds, and CPC were lower compared to those in corn and SBM, concentrations of omega-3 fatty acids (Linolenic: C18:3n3, and Homo-a-linolnic: C20:3n3) in camelina oil, seeds, and CPC were much higher than in corn and SBM. On the other hand, the concentration of the omega-6 fatty acid, linoleic (C18:2n6), was much lower in camelina oil, seeds, and CPC than in corn and SBM. The concentration of glucosinolates in camelina seeds and CPC were almost identical. The concentration of glucosinolates was negligible and trypsin inhibitors were not detected in camelina oil. Concentrations of trypsin inhibitor in camelina seeds and CPC were similar to that reported previously (Matthaus and Zubr, 2000; Woyengo et al., 2017). Because anti-nutritional factors were not expected in corn and SBM, 
TABLE 4 | Analyzed fatty acid profiles (\% of total fatty acids as-is basis) and concentration of selected antinutritional compounds of camelina oil, seed, press-cake, organic corn, and soybean meal (SBM).

\begin{tabular}{|c|c|c|c|c|c|}
\hline Item & Camelina oil & Camelina seed & Camelina press-cake & Organic corn & Organic SBM \\
\hline \multicolumn{6}{|c|}{ Saturated fatty acids (SFA), \% as-is basis ${ }^{a}$} \\
\hline Palmitic (C16:0) & 5.17 & 5.7 & 6.94 & 13.49 & 11.16 \\
\hline Stearic (C18:0) & 3.35 & 3.37 & 3.35 & 1.71 & 3.99 \\
\hline Arachidic (C20:0) & 1.99 & 1.95 & 1.92 & 0.5 & 0.3 \\
\hline Total SFA & 10.5 & 11.2 & 12.2 & 15.7 & 15.5 \\
\hline \multicolumn{6}{|c|}{ Monounsaturated fatty acids (MUFA), \% as-is basis ${ }^{a}$} \\
\hline Oleic (9c-C18:1) & 15.18 & 15.1 & 14.51 & 21.98 & 17.9 \\
\hline Caccenic (11c-18C:1) & 0.81 & 0.9 & 1.27 & 0.75 & 1.26 \\
\hline Gonodic (C20:1n9) & 13.71 & 13.01 & 11.09 & 0 & 0 \\
\hline Erucic (C22:1n9) & 2.38 & 2.30 & 2.28 & 0 & 0 \\
\hline Total MUFA & 32.1 & 31.3 & 29.2 & 22.7 & 19.2 \\
\hline \multicolumn{6}{|c|}{ Polyunsaturated fatty acids (PUFA), \% as-is basis ${ }^{a}$} \\
\hline Linoleic (C18:2n6) & 17.25 & 18.48 & 23.02 & 57.57 & 53.68 \\
\hline Linolenic $(\mathrm{C} 18: 3 n 3)^{b}$ & 34.55 & 33.32 & 28.55 & 2.08 & 9.57 \\
\hline Homo-a-linolnic $(\mathrm{C} 20: 3 n 3)^{\mathrm{b}}$ & 1.32 & 1.24 & 1.03 & 0 & 0 \\
\hline Total PUFA & 53.1 & 53.0 & 52.6 & 59.7 & 63.3 \\
\hline \multicolumn{6}{|l|}{ Antinutritional composition } \\
\hline Glucosinolates, $\mu \mathrm{mol} / \mathrm{g}$ & 0.46 & 24.6 & 24.5 & - & - \\
\hline Trypsin Inhibitor, TIU/mg & n.d. ${ }^{c}$ & 1.74 & 1.97 & - & - \\
\hline
\end{tabular}

${ }^{a} W / W \%=$ grams per 100 grams of samples. Only fatty acids $>1 \%$ of total fatty acids are reported.

${ }^{b}$ Omega-3 fatty acids.

${ }^{c}$ Not detectable.

glucosinolates and trypsin inhibitors were not analyzed for corn and SBM.

\section{Effects of Supplementing Camelina Press-Cake on Pig Performance and Pork Quality}

Pigs fed diets supplemented with CPC consumed less feed $(P=0.05$; Table 5), gained less weight $(P=0.001)$, and were lighter $(P=0.001)$ at conclusion of the study compared to pigs fed control diets. Gain efficiency $(\mathrm{G}: \mathrm{F})$ was not affected by dietary treatment. Twelve pigs $(6 \%)$ in the control group and six pigs (3\%) in treatment group could not be marketed at the end of the study because they were too light, were lame, displayed a belly rupture or died. But no statistical differences in total mortality and morbidity were detected between control and treatment groups. For pigs that were marketed and harvested at the meat processing plant, hot carcass weight was lighter $(P=0.001)$, dressing percentage was lower $(P=0.03)$, backfat thickness at the last rib was less $(P=0.04)$, and lean percentage was greater $(P=0.04)$ for pigs fed treatment diets compared with pigs fed control diets.

Interactions between dietary treatment and week were detected for ADFI, ADG, and body weight. Pigs fed treatment diets displayed reduced ADFI $(P<0.05)$ during the initial 4 weeks of the study, compared to pigs fed control diets (Figure 1). After 4 weeks, no difference was detected in ADFI between the two groups. Similar to ADFI, ADG was reduced during the initial 4 weeks in pigs fed treatment diets compared with pigs fed control diets (Figure 2). After 4 weeks, differences in ADG between the two groups were not significant. Body weight of pigs fed treatment diets was lighter (Figure 3; all $P<0.05)$ at weeks $14,18,22$, and 24 compared to pigs fed control diets.

For focal pigs harvested to evaluate pork quality, body weight at harvest and hot carcass weight were lighter (all $P<0.05$; Table 6) in pigs fed treatment diets compared to pigs fed control diets. Differences in dressing and lean percentage between the two groups were not statistically significant. Additionally, dietary treatment had no effects on any other carcass, pork or belly traits measured except for backfat thickness at the last lumbar vertebra. Backfat thickness at the last lumbar vertebra was less $(P=0.03)$ in focal pigs fed treatment diets than that in pigs fed control diets. In addition, focal pigs fed treatment diets had heavier livers $(P=0.03$ for liver weight, and $P=0.04$ for liver weight as a percentage of final body weight) than pigs fed control diets.

\section{Economic Analysis}

For the scenario of the typical 3-year rotation, the average net return to land during the year of planting organic soybeans was $\$ 708 \mathrm{ha}^{-1}$, assuming that the average organic soybean yield was $2,268 \mathrm{~kg} \mathrm{ha}^{-1}$ and growing costs was $\$ 630 \mathrm{ha}^{-1}$ 
TABLE 5 | Growth performance and carcass traits of pigs supplemented with dietary camelina press-cake under near-organic conditions.

\begin{tabular}{|c|c|c|c|c|}
\hline \multirow[t]{2}{*}{ Item } & \multicolumn{2}{|c|}{ Dietary treatment } & \multirow{2}{*}{$\begin{array}{c}\text { Pooled } \\
\text { SE }\end{array}$} & \multirow[b]{2}{*}{$P$-value ${ }^{\text {a }}$} \\
\hline & Control & Camelina & & \\
\hline No. of pens & 4 & 4 & - & - \\
\hline No. of pigs & 198 & 198 & - & - \\
\hline \multicolumn{5}{|l|}{ Body weight, kg } \\
\hline Initial (10 wk of age) & 28.1 & 27.4 & 0.37 & 0.24 \\
\hline Final $(24 \text { wk of age })^{b}$ & 130.0 & 123.5 & 0.73 & 0.001 \\
\hline ADFI, kg & 2.95 & 2.77 & 0.047 & 0.046 \\
\hline $\mathrm{ADG}, \mathrm{kg}$ & 1.08 & 1.01 & 0.007 & 0.001 \\
\hline Gain:Feed & 0.37 & 0.36 & 0.004 & 0.32 \\
\hline Morbidity and mortality ${ }^{\mathrm{C}}, \%$ & 6.1 & 3.0 & - & 0.15 \\
\hline \multicolumn{5}{|l|}{ Carcass traits } \\
\hline No. of pigs & 170 & 176 & - & - \\
\hline Hot carcass weight ${ }^{\mathrm{b}}, \mathrm{kg}$ & 95.2 & 88.7 & 0.64 & 0.001 \\
\hline Dressing $^{\mathrm{d}}, \%$ & 73.0 & 71.7 & 0.31 & 0.03 \\
\hline Backfat thickness ${ }^{e, f}, \mathrm{~mm}$ & 22.9 & 21.8 & 0.28 & 0.04 \\
\hline Carcass lean ${ }^{e, g}, \%$ & 52.5 & 53.0 & 0.12 & 0.04 \\
\hline
\end{tabular}

${ }^{a}$ Pen was the experimental unit.

${ }^{b}$ Initial weight was used as a covariate.

cIncluded pigs that were not marketed because they died on the farm, were dead on arrival (DOA) at the parking plant, were lame, were too light $(<90 \mathrm{~kg})$, or displayed a belly rupture as percent of total pigs assigned to the experiment (Chi-square $=2.10, d f=1$ ). ${ }^{d}$ Final weight was used as a covariate.

e Hot carcass weight was used as a covariate.

${ }^{f}$ Backfat thickness was measured at the last rib.

${ }^{g}$ Fat-free lean $(\%)=[23.568+1.107 \times$ hot carcass weight $(\mathrm{kg})-8.405 \times$ last rib backfat depth $(\mathrm{cm})$ ]/hot carcass weight $(\mathrm{kg}) \times 100$ [National Pork Producer Council (NPPC), 2000].

[University of Minnesota Center for Farm Financial Management (CFFM), 2021].

The soybean yield in the relay-cropping field in the current study was $1,210 \mathrm{~kg} \mathrm{ha}^{-1}$, which was a reduction of $1,058 \mathrm{~kg}$ or $46.6 \%$ compared with the University of Minnesota Center for Farm Financial Management (CFFM) (2021) average. At a price of $\$ 0.59 \mathrm{~kg}^{-1}$, the soybean yield reduction if relay planting results in a revenue reduction of $\$ 624 \mathrm{ha}^{-1}$ (Table 7). It is assumed that the soybean growing costs of $\$ 630 \mathrm{ha}^{-1}$ are unchanged regardless of mono- or relay-cropping camelina. If the camelina is monocropped with no soybeans following it, the entire $2,268 \mathrm{~kg}$ soybean yield is lost which results in lost soybean revenues of $\$ 1,338 \mathrm{ha}^{-1}$. However, this lost revenue is partially offset by the avoided soybean growing cost of $\$ 630 \mathrm{ha}^{-1}$, so that the reduction in net return is $\$ 708$. Conventional tillage is assumed for the camelina seeding, and costs $\$ 246 \mathrm{ha}^{-1}$ based on machinery purchased new in 2020. Adding the cost of the camelina seed and interest on the preharvest expenses until harvest, and deducting a small amount of cover crop expense that organic wheat enterprises are currently incurring, the total of the costs and reduced revenues is $\$ 883 \mathrm{ha}^{-1}$ for the relay-planting scenario and $\$ 967$ $\mathrm{ha}^{-1}$ for the monocropping scenario. Dividing by the relayplanted camelina yield $\left(684 \mathrm{~kg} \mathrm{ha}^{-1}\right)$ shows that the camelina seed would need to be sold at a minimum price of $\$ 1.29$ $\mathrm{kg}^{-1}$ to cover those costs and reduced revenues. For the monocrop scenario, dividing by the camelina yield of $1,394 \mathrm{~kg}$ $\mathrm{ha}^{-1}$ translates to a minimum sale price of $\$ 0.69 \mathrm{~kg}^{-1}$ for the camelina seed.

Lower minimum sale price indicates improved economic feasibility. The lower minimum sale price of camelina seed in the monocrop scenario (\$0.69 compared with $\$ 1.29$ in the relay scenario) is counterintuitive because the camelina yield in the monocrop field was lower than the total yield of camelina plus soybeans in the relay-cropping scenario, but the economical feasibility is improved by the difference in the soybean growing cost. Thus, growing cost savings is an important factor affecting economical feasibility along with the yield differences.

A maximum allowable purchase price for CPC was calculated based on the difference in per-pig gross income and feed cost between the two treatment groups (control vs. treatment, Table 8). The average feed cost for the control diet was $\$ 140 \mathrm{pig}^{-1}$ while the average feed cost for the treatment diet was $\$ 121 \mathrm{pig}^{-1}$, which would be a feed cost savings of $\$ 19.12 \mathrm{pig}^{-1}$ if not accounting for the CPC cost. Dividing this $\$ 19.12$ by the $26.3 \mathrm{~kg}$ of CPC in the treatment diet shows that the CPC can be purchased for no more than $\$ 0.73 \mathrm{~kg}^{-1}$ in order for the total treatment diet cost to remain at or below the cost of the control diet, ignoring the $5.8 \mathrm{~kg}$ difference in weight gain between pigs in the two groups.

The reduction in total weight gain $\left(5.80 \mathrm{~kg} \mathrm{pig}^{-1}\right)$ of pigs fed the treatment diet in the current study represents a gross income reduction of $\$ 13.94 \mathrm{pig}^{-1}$, based on a sale price for organically-grown pigs of $\$ 2.40 \mathrm{~kg}^{-1}$ live weight. Subtracting this gross income reduction ( $\$ 13.94 \mathrm{pig}^{-1}$ ) from the feed cost savings $\left(\$ 19.12 \mathrm{pig}^{-1}\right.$ ) leaves $\$ 5.18 \mathrm{pig}^{-1}$ as the maximum amount that a producer should be willing to pay for CPC in order to achieve a net return at or above that of the control diet. Dividing this $\$ 5.18 \mathrm{pig}^{-1}$ maximum by the $26.3 \mathrm{~kg}$ of CPC fed to pigs shows that the maximum allowable price for the $\mathrm{CPC}$ is $\$ 0.20 \mathrm{~kg}^{-1}$.

Pressing camelina seed yields CPC at $80.5 \%$ in the current study. For the relay-planting scenario, the minimum camelina seed price of $\$ 1.29 \mathrm{~kg}^{-1}$ translates to a minimum CPC price of $\$ 1.60 \mathrm{~kg}^{-1}$ after pressing if no value is assigned to the oil (Table 9). The difference between the minimum CPC sale price $\left(\$ 1.60 \mathrm{~kg}^{-1}\right)$ and the maximum allowable CPC purchase price $\left(\$ 0.20 \mathrm{~kg}^{-1}\right)$ that the pig producer should be willing to pay for the CPC leaves a deficit of $\$ 1.41 \mathrm{~kg}^{-1}$ of CPC or $\$ 1.13 \mathrm{~kg}^{-1}$ of seed. It may be possible to make up this deficit by marketing the camelina oil. Camelina oil yield was $14.7 \%$ of seed weight in the current study, so that $6.8 \mathrm{~kg}$ of seed is required to produce one $\mathrm{kg}$ of oil. Multiplying $6.8 \mathrm{~kg}$ seed by the deficit of $\$ 1.13 \mathrm{~kg}^{-1}$ of seed, the minimum oil price required to make up the deficit is $\$ 7.71 \mathrm{~kg}^{-1}$ of oil for the relay-planting scenario.

The minimum CPC sale price is $\$ 0.66 \mathrm{~kg}^{-1}$ in the monocrop scenario, which translates into a minimum oil sale price of $\$ 3.59 \mathrm{~kg}^{-1}$ for the monocrop scenario based on similar calculations. 


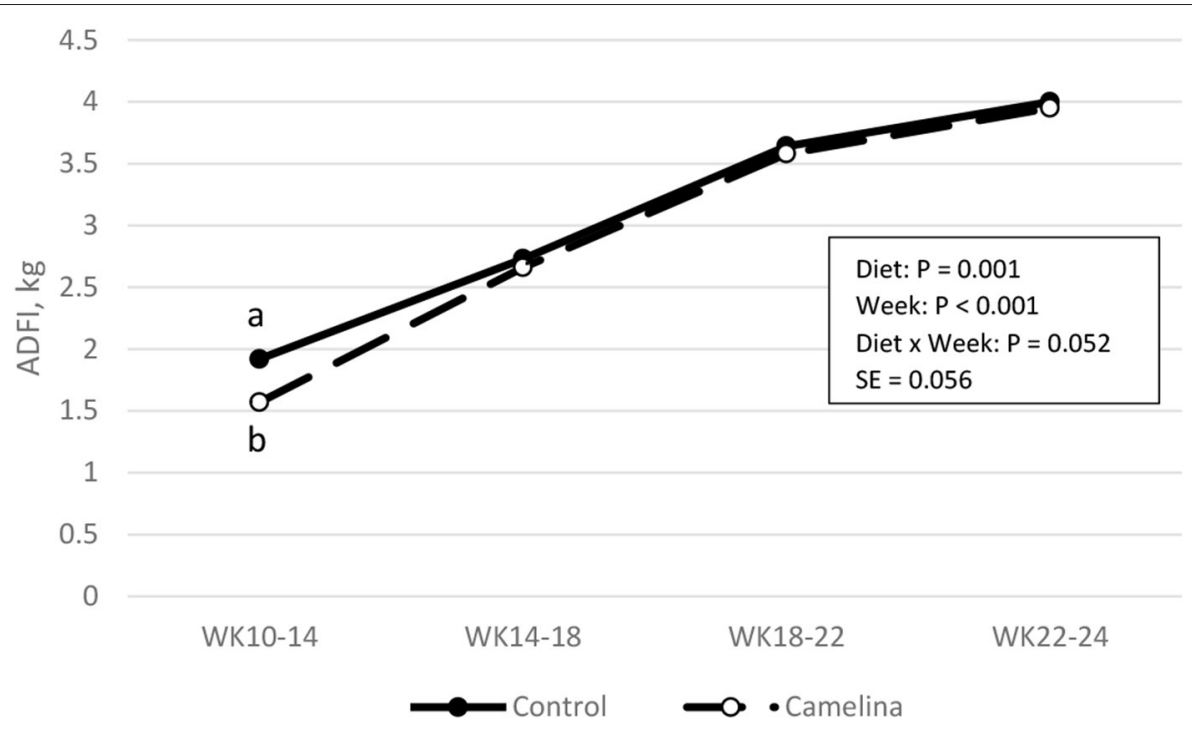

FIGURE 1 | Average daily feed intake of pigs over 14 weeks of the study (Initial body weight was used as a covariate; four pens/treatment). ab Means within the same period with different superscripts differ $(P<0.05)$.



FIGURE 2 | Average daily gain of pigs over 14 weeks of the study (Initial body weight was used as a covariate; four pens/treatment). ${ }^{\text {ab }}$ Means within the same period with different superscripts differ $(P<0.05)$.

\section{DISCUSSION}

This study was the first to explore growing winter camelina in organically certified land in the Midwest of the United States. In the current study, camelina seed yield $\left(1,394 \mathrm{~kg} \mathrm{ha}^{-1}\right)$ in the monocrop field was comparable to that in conventional cropping systems (Gesch et al., 2018: $865 \mathrm{~kg} \mathrm{ha}^{-1}$; Hoerning et al., 2020: $1100-2700 \mathrm{~kg} \mathrm{ha}^{-1}$ ). This may be attributed to the fact that camelina requires minimal fertilizer, and it suppresses weeds. Johnson et al. (2019) demonstrated that sufficient winter camelina seed yields can be achieved with as little as $34-50 \mathrm{~kg} \mathrm{ha}^{-1}$ of soil available nitrogen. This indicates that in fields where residual soil available nitrogen is already at these levels, such as after corn production, additional nitrogen fertilizer may not be necessary for camelina growth. Additionally, Hoerning et al. (2020) reported that summer annual weed growth the following spring was greatly suppressed by actively-growing winter camelina. Without any application of herbicides, weeds were not a problem either in the spring or summer in both camelina fields (monocrop and relay-crop) in the current study. Camelina suppressed weeds in the soybean field up to camelina maturity. 


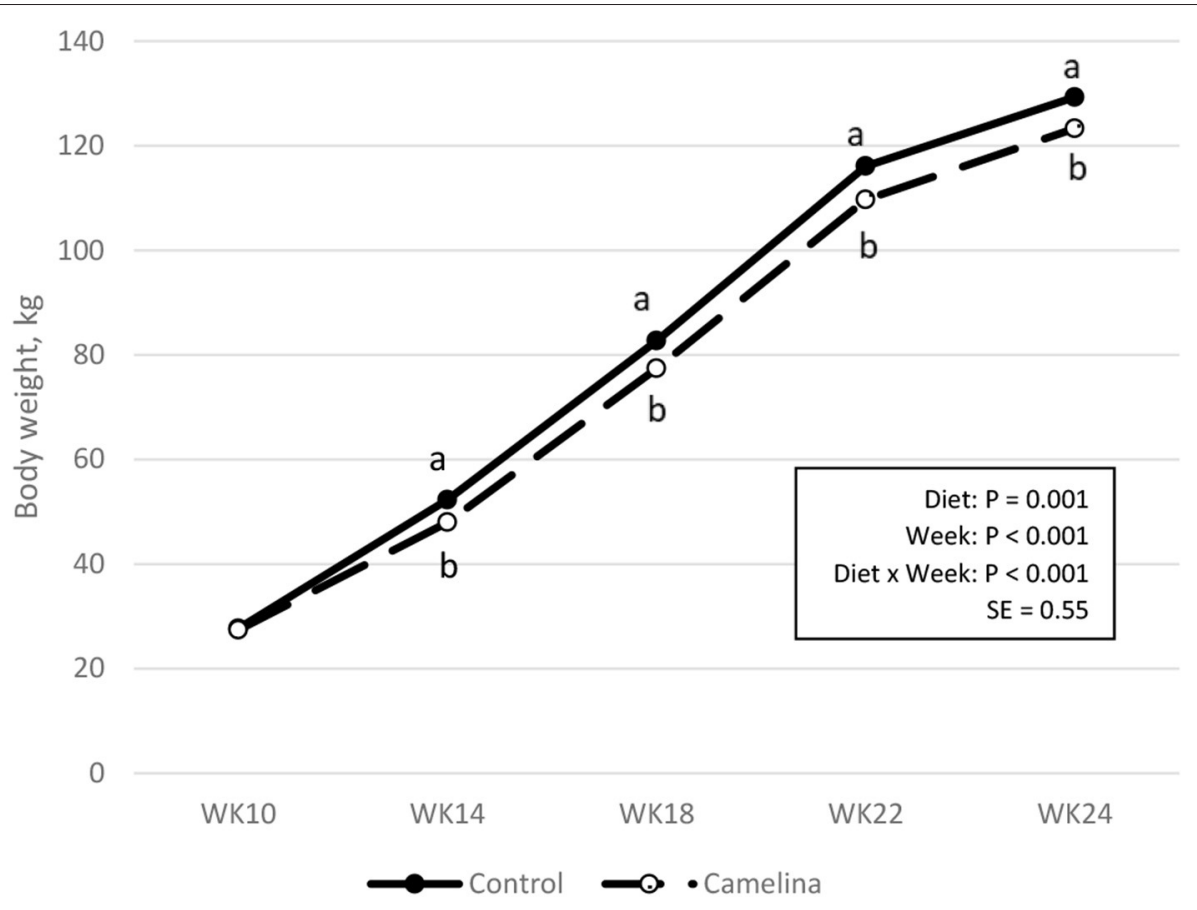

FIGURE 3 | Body weight of pigs over 14 weeks of growing-finishing period (Initial weight was used as a covariate; four pens/treatment). ${ }^{\text {ab }}$ Means within the same period with different superscripts differ $(P<0.05)$.

However, after camelina harvest, weeds grew quickly through the open canopy and competed with soybeans in the relay cropped field.

Late season weed pressure likely affected soybean yield in the relay field. In the current study, soybean yield in the relay crop field was $53 \%$ of average soybean yields $(2,268 \mathrm{~kg}$ $\mathrm{ha}^{-1}$ ) reported by the University of Minnesota Center for Farm Financial Management (CFFM) (2021). The camelina yield in the relay crop field was $49 \%$ of the camelina yield in the monocrop field in the current study, which was also lower than expected. The low camelina yield in the relay field could be associated with the way that camelina was harvested. During harvest, camelina was cut $30 \mathrm{~cm}$ above the ground in the relaycrop field (compared to $20 \mathrm{~cm}$ in the monocrop field) to avoid cutting the soybeans. The difference in cutting height between the monocrop and relay cropping field may be associated with the lower yield of camelina in the latter field because camelina seed pods between 20 and $30 \mathrm{~cm}$ were not harvested. Consequently, the total oilseed yield (camelina plus soybean) in the relay field was lower in the current study than that reported in conventional crop systems (Gesch et al., 2014). By comparing two cropping systems, monocropping (soybean only) vs. relay cropping (soybean relayed with winter camelina), Gesch et al. (2014) estimated that including camelina in the relay cropping system increased total oil seed yield by nearly $50 \%$. The total oil seed (camelina plus soybean) yield in the relay field was $1,894 \mathrm{~kg}$ $\mathrm{ha}^{-1}$ in the current study, accounting for $136 \%(1,894 / 1,394$ $\times 100 \%)$ of the camelina yield and $84 \%(1,894 / 2,268 \times 100 \%)$ of the soybean yield in the monocrop field. In other words, compared to camelina-only cropping, relay cropping (camelina with soybeans) increased total oil seed yield by $36 \%$. However, compared to monocrop soybean, relay cropping decreased total oil seed yield by $16 \%$. Cultivation was not used in this study, but could have been a method to control late-season weeds organically in the relay system. In addition to relaying a short season crop like soybean, a forage crop could be grown instead. Swathing could also be used to help desiccate the camelina earlier and then one could potentially plant soybeans afterwards. Much more research can be done on this system, and there is good potential to increase the profitability and total yield per hectare.

Dietary CPC supplementation reduced ADFI and consequently reduced $\mathrm{ADG}$ in pigs in the current study as observed in previous work (Smit and Beltranena, 2017; Hilbrands et al., 2021). The reduced ADFI could be attributed to glucosinolates in CPC. In the current study, the analyzed concentration of glucosinolates in CPC supplemented diets was $2.1 \mu \mathrm{mol} / \mathrm{g}$ of feed, which was slightly higher than the suggested maximal amount of glucosinolate $(2.0 \mu \mathrm{mol} / \mathrm{g}$ of feed $)$ to avoid negative effect on growth performance in pigs (Almeida et al., 2013; Meadus et al., 2014). Woyengo et al. (2017) reported that pigs could tolerate up to $2.5 \mu \mathrm{mol} / \mathrm{g}$ of glucosinolates in their diets and reduced ADFI by $80 \mathrm{~g}$ when dietary glucosinolates was increased to $3.5 \mu \mathrm{mol} / \mathrm{g}$ of feed. Pigs in the current study appeared to be more sensitive to glucosinolates than pigs in Woyengo et al. (2017)'s study. Erucic acid concentration in CPC was $2.3 \%$ of total fatty acids (crude fat) in the current study. Because CPC contained 9.3\% crude fat, the calculated 
TABLE 6 | Carcass traits, belly firmness, pork quality, and liver weight of focal pigs.

\begin{tabular}{|c|c|c|c|c|}
\hline \multirow[t]{2}{*}{ Item } & \multicolumn{2}{|c|}{ Dietary treatment } & \multirow{2}{*}{$\begin{array}{c}\text { Pooled } \\
\text { SE }\end{array}$} & \multirow[b]{2}{*}{$P$-value ${ }^{a}$} \\
\hline & Control & Camelina & & \\
\hline No. of pens & 2 & 2 & & \\
\hline No. of pigs & 16 & 16 & & \\
\hline \multicolumn{5}{|l|}{ Body weight, kg } \\
\hline Initial & 29.9 & 27.7 & 0.87 & 0.22 \\
\hline Final (at harvest) ${ }^{b}$ & 134.4 & 123.0 & 1.76 & 0.045 \\
\hline Hot carcass weight ${ }^{b}, \mathrm{~kg}$ & 98.3 & 90.1 & 1.00 & 0.03 \\
\hline Dressing $^{\mathrm{C}}, \%$ & 73.9 & 72.6 & 0.46 & 0.23 \\
\hline Carcass lean ${ }^{\mathrm{d}, \mathrm{e}}, \%$ & 52.5 & 52.6 & 0.57 & 0.86 \\
\hline Carcass length, cm & 87.1 & 86.5 & 1.09 & 0.74 \\
\hline Loin eye muscle area ${ }^{d}, \mathrm{~cm}^{2}$ & 62.9 & 57.4 & 9.59 & 0.73 \\
\hline \multicolumn{5}{|l|}{ Backfat thickness $^{d}, \mathrm{~cm}$} \\
\hline 1st rib & 3.1 & 3.4 & 0.50 & 0.74 \\
\hline 10th rib & 2.0 & 1.8 & 0.14 & 0.50 \\
\hline Last rib & 2.3 & 2.2 & 0.14 & 0.81 \\
\hline Last lumbar & 1.8 & 1.3 & 0.15 & 0.03 \\
\hline \multicolumn{5}{|l|}{ Belly firmness } \\
\hline Thickness, cm & 4.9 & 5.1 & 0.17 & 0.57 \\
\hline Hang angle ${ }^{f}$, degrees & 29.9 & 24.1 & 4.55 & 0.44 \\
\hline Adjusted hang angle ${ }^{g}$, degrees & 30.0 & 24.0 & 4.62 & 0.43 \\
\hline \multicolumn{5}{|l|}{ Pork quality } \\
\hline \multicolumn{5}{|l|}{$\mathrm{pH}$ value } \\
\hline 45 min post-mortem & 5.85 & 5.98 & 0.09 & 0.42 \\
\hline $24 \mathrm{~h}$ post-mortem & 5.87 & 5.99 & 0.33 & 0.81 \\
\hline \multicolumn{5}{|l|}{ Water holding capacity, \% } \\
\hline Drip loss & 3.8 & 3.5 & 0.48 & 0.69 \\
\hline Purge loss & 4.5 & 4.1 & 1.35 & 0.84 \\
\hline Cook loss & 16.2 & 15.3 & 1.75 & 0.77 \\
\hline Shear force, $N$ & 22.8 & 26.4 & 2.11 & 0.35 \\
\hline Color score ${ }^{h}$ & 2.6 & 2.9 & 0.16 & 0.29 \\
\hline Marbling score ${ }^{i}$ & 1.4 & 1.5 & 0.18 & 0.83 \\
\hline Liver weight $^{\mathrm{C}}, \mathrm{kg}$ & 1.73 & 2.20 & 0.06 & 0.03 \\
\hline Liver weight/final body weight, \% & 1.36 & 1.69 & 0.04 & 0.04 \\
\hline
\end{tabular}

${ }^{a}$ Pen was the experimental unit.

${ }^{b}$ Initial weight was used as a covariate.

${ }^{c}$ Final weight was used as a covariate. Dressing (\%) $=[$ Hot carcass weight/final body weight] $\times 100$.

${ }^{d}$ Hot carcass weight was used as a covariate.

${ }^{e}$ Fat-free lean $(\%)=\{[23.568+1.107 \times$ hot carcass weight $(\mathrm{kg})-8.405 \times$ last rib backfat depth $(\mathrm{cm})] /$ hot carcass weight $(\mathrm{kg})\} \times 100$ [National Pork Producer Council (NPPC), 2000].

${ }^{f}$ Hang angle was the upper angle of the isosceles triangle created by hanging the belly over a smokehouse stick. The angle was calculated using belly length and hang distance. Belly angle $($ degree $)=\cos ^{-1}\left[\left(0.5 \times\right.\right.$ belly length ${ }^{2}-$ hang distance $\left.{ }^{2}\right) /\left(0.5 \times\right.$ belly length $\left.\left.{ }^{2}\right)\right]$. ${ }^{g}$ Belly thickness was used as a covariate.

${ }^{h}$ From Score $1=$ very bright reddish pink to Score $6=$ tan to brown.

${ }^{i}$ From Score $1=1 \%$ intramuscular fat to Score $6=6 \%$ intramuscular fat.

erucic acid concentrations were $0.21 \%$ in CPC and $0.021 \%$ in treatment diets. The allowable amount of erucic acid in canola seed is 2\% [Canadian Food Inspection Agency (CFIA), 2011]. Thus, erucic acid concentration $(0.021 \%)$ in treatment diets in the current study was estimated to be below the level that could cause any negative effect on pig performance (Meadus et al., 2014). Supplementation of CPC in diets did not affect gain efficiency in the current study, which was consistent with results of previous work (Smit and Beltranena, 2017; Hilbrands et al., 2021). Interestingly, reduced ADFI and ADG was observed only during the initial 4 weeks of the dietary treatment in the current study. Four weeks later, differences in ADFI and ADG were not detectable between the two treatment groups. These results are different from results of Smit and Beltranena (2017) and Hilbrands et al. (2021) who reported that CPC supplementation reduced ADFI and ADG in pigs throughout the growing-finishing period in conventional housing systems. It appears that pigs in the current study adapted to the CPC supplemented diets in 4 weeks. Glucosinolates in CPC are considered bitter (Fenwick et al., 1982; van Doorn et al., 1998) and reduce palatability of pigs (NÍ Eidhin et al., 2003). Possibly, the bitter taste of CPC supplemented diets reduced the ADFI in pigs during the initial period. After 4 weeks, pigs became tolerant to the bitter taste of CPC supplemented diets. Regardless of the differences between this study and previous work, all three studies demonstrated that dietary CPC supplementation reduced market weight, hot carcass weight, and dressing percentage of pigs which suggests CPC supplementation may reduce market value of pigs. In the current study, pigs fed treatment diets were $6.5 \mathrm{~kg}$ lighter than pigs fed control diets at market. Theoretically, pigs fed treatment diets would require an additional 6-7 days (based on ADG of $1.01 \mathrm{~kg}$ ) to reach the final body weight of pigs fed control diets.

At the meat processing plant, pigs fed CPC supplemented diets yielded higher percent lean than pigs fed control diets in the current study. Similar results have been reported by Smit and Beltranena (2017) and Zhu et al. (2021), but not by Hilbrands et al. (2021). Additionally, difference in lean percentage between the treatment and control groups was not detected in focal pigs in the current study. Thus, effects of dietary CPC supplementation on lean percentage need to be confirmed in future research.

Data collected from focal pigs demonstrated that CPC supplementation did not elicit notable effects on pork quality in the current experiment. These results are consistent with previous work (Smit and Beltranena, 2017; Zhu et al., 2021). The current study also demonstrated that dietary CPC increased liver weight in pigs, indicating that glucosinolates in CPC increased metabolic burden on the liver (Smit and Beltranena, 2017). Furthermore, increased liver weight likely contributed to reduced dressing percentage observed in pigs fed treatment diets.

In conventional cropping systems, the yields of corn and soybeans are maintained by applications of synthetic fertilizers, herbicides, and pesticides, which are not allowed in organic production. Thus, organic farmers look for ecological approaches, such as diverse rotations and introducing new cover crops to control weeds and pests and enhance soil health. Consequently, cover crops are of interests to organic crop farmers. Pirvan et al. (2020) envisioned that utilizing cover crops for animal feed will be the key for sustainable cover crop production. 
TABLE 7 | Calculation of camelina seed minimum sale price required to cover the cost of growing the camelina and reduced yield of soybeans caused by relay- or mono-cropping camelina compared with monocrop soybeans, per hectare.

\begin{tabular}{|c|c|c|c|}
\hline & $\begin{array}{l}\text { Monocrop organic } \\
\text { soybeans }^{\text {a }}\end{array}$ & $\begin{array}{l}\text { Camelina relay-planting } \\
\text { with soybeans }^{\text {b }}\end{array}$ & Monocrop camelina ${ }^{b}$ \\
\hline $\begin{array}{l}\text { Base scenario that does not contain camelina, soybean year of } \\
\text { the rotation: } \\
\text { Soybean yield, } \mathrm{kg}\end{array}$ & 2,268 & & \\
\hline Soybean revenue @ \$0.5916 kg ${ }^{-1}$ & $\$ 1,338$ & & \\
\hline Soybean growing costs & $-\$ 630$ & & \\
\hline Net return & $\$ 708$ & & \\
\hline \multicolumn{4}{|l|}{$\begin{array}{l}\text { Scenarios containing camelina: } \\
\text { Camelina growing costs: }\end{array}$} \\
\hline Seed, $7.8 \mathrm{~kg} @ \$ 0.40 \mathrm{~kg}^{-1}$ & $-\$ 3$ & & \\
\hline Machinery and labor & $-\$ 246$ & & \\
\hline Interest on pre-harvest expenses (6 months @ 5\%) & $-\$ 3$ & & \\
\hline Total camelina growing costs & $-\$ 252$ & & \\
\hline Soybean yield, kg & & 1,210 & 0 \\
\hline Soybean revenue @ \$0.5916 kg ${ }^{-1}$ & & $\$ 714$ & $\$ 0$ \\
\hline Soybean growing costs & & $-\$ 630$ & $\$ 0$ \\
\hline Soybean net return & & $\$ 84$ & $\$ 0$ \\
\hline Difference in soybean yield compared with base, $\mathrm{kg}$ & & $-1,058$ & $-2,268$ \\
\hline Difference in soybean revenue, \$ ha ${ }^{-1} @ \$ 0.59 \mathrm{~kg}^{-1}$ & & $-\$ 624$ & $-\$ 1,338$ \\
\hline Avoided soybean growing costs from not planting the soybeans & & $\$ 0$ & $\$ 630$ \\
\hline Difference in soybean net return & & $-\$ 624$ & $-\$ 708$ \\
\hline $\begin{array}{l}\text { Savings from wheat cover crop expenses replaced by the } \\
\text { camelina }\end{array}$ & & $-\$ 7$ & $-\$ 7$ \\
\hline Total costs related to camelina & & $-\$ 883$ & $-\$ 967$ \\
\hline Camelina yield, $\mathrm{kg}$ & & 684 & 1,394 \\
\hline Minimum camelina seed sale price required to cover costs, $\$ \mathrm{~kg}^{-1}$ & & $-\$ 1.29$ & $-\$ 0.69$ \\
\hline Total yield of camelina and soybeans & & 1,894 & 1,394 \\
\hline $\begin{array}{l}\text { Difference in total yield compared with soybean yield in base } \\
\text { scenario }\end{array}$ & & -374 & -874 \\
\hline
\end{tabular}

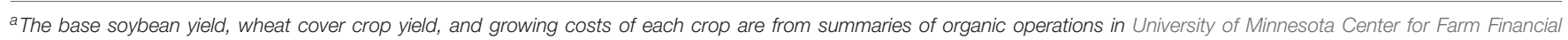
Management (CFFM) (2021).

${ }^{b}$ Camelina and soybean yield in relay-planting, camelina yield in mono-cropping, and camelina seed cost are from the current study.

The machinery types, sizes, and costs per hectare are from Lazarus (2020).

The economic analysis of the current study indicates that the minimum camelina seed sale price is $\$ 1.29 \mathrm{~kg}^{-1}$ of seed if relay-planting or $\$ 0.69 \mathrm{~kg}^{-1}$ if monocropping. During the study period, the negotiated conventional camelina seed price in the Midwest was between $\$ 0.55 \mathrm{~kg}^{-1}$ and $\$ 1.09 \mathrm{~kg}^{-1}$ (Albert Lea Seed, Albert Lee, MN.). The market for organic camelina seed has not been established in the United States. Translating the quality of camelina seeds to the quantity of CPC, the calculated minimum CPC sale price is $\$ 1.60 \mathrm{~kg}^{-1}$ or $\$ 0.66 \mathrm{~kg}^{-1}$ for the two scenarios compared to the maximum purchase price of $\$ 0.20$ $\mathrm{kg}^{-1}$ that the organic pig producer would be willing to pay. Those sale prices are based on the market price of organically-raised hogs being $\$ 2.40 \mathrm{~kg}^{-1}$ (live weight). That difference then is $\$ 1.40$ $\mathrm{kg}^{-1}$ (\$1.60-\$0.20) if relay-planting or $\$ 0.46 \mathrm{~kg}^{-1}(\$ 0.66-\$ 0.20)$ if monocropping, which would need to be made up from the value of the co-product camelina oil. The market for organically-raised hogs in Minnesota is also currently not very well-established, so this price may vary in the future. The calculated minimum camelina oil sale price was $\$ 7.71 \mathrm{~kg}^{-1}$ if relay-planting or $\$ 3.59 \mathrm{~kg}^{-1}$ if monocropping without including processing and marketing costs in the current study. Camelina oil is mainly used as biodiesel and biofuel in the U.S. Dangol et al. (2020) reported that the costs of ingredients and utilities to make biodiesel and biofuel from conventional camelina oil were $\$ 0.75 \mathrm{~L}^{-1}(\$ 0.82$ $\left.\mathrm{kg}^{-1}\right)$ and $\$ 2.19 \mathrm{~L}^{-1}\left(\$ 2.38 \mathrm{~kg}^{-1}\right)$, respectively. Assuming that these costs represent the current price of conventional camelina oil, this suggests that the current biofuel market is far below what would be required to encourage camelina production in an organic crop and pig production system. Collectively, results of the current study suggest that the viability of integrating camelina into organic swine production would depend on market development for organic pigs and camelina oil. Monocropping camelina appears more economically feasible than relay-planting it with a following soybean crop based on these results. 
TABLE 8 | Minimum camelina press-cake purchase price based on the difference between pig market value and organic feed cost with and without a 10 percent camelina press-cake inclusion rate.

\begin{tabular}{|c|c|c|c|c|}
\hline & Control & & Camelina & \\
\hline Starting weight, $\mathrm{kg}$ & & 28.1 & & 27.4 \\
\hline Ending weight, $\mathrm{kg}$ & & 130.0 & & 123.5 \\
\hline Gain, kg & & 101.9 & & 96.1 \\
\hline \multicolumn{5}{|l|}{ Diet: } \\
\hline Corn, kg & $69.9 \%$ & 190.0 & $63.8 \%$ & 167.8 \\
\hline Soybean meal, kg & $27.5 \%$ & 74.8 & $23.8 \%$ & 62.7 \\
\hline Base mix, kg & $2.6 \%$ & 7.0 & $2.4 \%$ & 6.3 \\
\hline Camelina press-cake, kg & & & $10.0 \%$ & 26.3 \\
\hline Total diet & $100.0 \%$ & 271.7 & $100.0 \%$ & 263.2 \\
\hline Feed cost/pig at corn $\left(\$ 0.35 \mathrm{~kg}^{-1}\right)$, soybean meal $\left(\$ 0.88 \mathrm{~kg}^{-1}\right)$, and base mix $\left(\$ 1.23 \mathrm{~kg}^{-1}\right)^{\mathrm{a}}$ & & $\$ 140.22$ & & $\$ 121.10$ \\
\hline Camelina value ignoring pig weight difference, \$/pig & & & & $\$ 19.12$ \\
\hline Maximum camelina press-cake purchasing price ignoring pig weight difference, $\$ \mathrm{~kg}^{-1}$ & & & & $\$ 0.73$ \\
\hline Difference in live weight gain, $\mathrm{kg}$ & & & & -5.80 \\
\hline Value of the pig market weight difference @ $\$ 2.40 \mathrm{~kg}^{-1}, \$ / \mathrm{pig}^{-1}$ & & & & $-\$ 13.94$ \\
\hline Camelina value considering pig weight difference, $\$$ pig $^{-1}$ (\$19.12-\$13.94) & & & & $\$ 5.18$ \\
\hline Maximum camelina press-cake purchase price considering pig weight difference, $\$ \mathrm{~kg}^{-1}(\$ 5.18 / 26.3 \mathrm{~kg})$ & & & & $\$ 0.20$ \\
\hline
\end{tabular}

The diet composition data and the price of base mix are from the pig feeding trial in the current study.

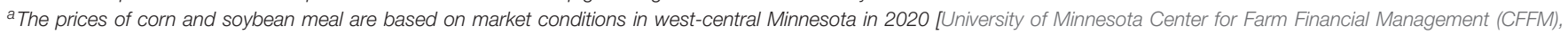
2021].

TABLE 9 | Calculation of minimum oil price (net of processing and marketing costs) required to equal economic feasibility of an organic system without camelina production or feeding pigs CPC.

\begin{tabular}{|c|c|c|c|c|}
\hline & Both scenarios & Relay scenario & Monocrop scenario & \\
\hline $\begin{array}{l}\text { Calculate the difference between the camelina } \\
\text { press-cake breakeven sale and purchase prices: } \\
\text { Minimum camelina seed sale price required to cover } \\
\text { costs, from Table } 7\end{array}$ & & $\$ 1.29$ & $\$ 0.69$ & $/ \mathrm{kg}$ of seed \\
\hline Presscake, \% of seed & $80.5 \%$ & & & $\%$ of seed \\
\hline $\begin{array}{l}\text { Minimum CPC sale price based on seed price and } \\
\text { press rate, before considering oil value }\end{array}$ & & $\$ 1.60$ & $\$ 0.85$ & $/ \mathrm{kg}$ of $\mathrm{CPC}$ \\
\hline Maximum CPC purchase price, from Table 8 & $\$ 0.20$ & & & $/ \mathrm{kg}$ of $\mathrm{CPC}$ \\
\hline $\begin{array}{l}\text { Difference between CPC minimum sale and } \\
\text { maximum purchase price, needed from oil value }\end{array}$ & & $\$ 1.41$ & $\$ 0.66$ & $/ \mathrm{kg}$ of $\mathrm{CPC}$ \\
\hline $\begin{array}{l}\text { Calculate the oil value required to make up the } \\
\text { difference between CPC minimum sale and } \\
\text { maximum purchase price: } \\
\text { Seed required to obtain } 1 \mathrm{~kg} \text { of CPC }\end{array}$ & 1.24 & & & $/ \mathrm{kg}$ of seed \\
\hline $\begin{array}{l}\text { Difference between seed minimum sale and } \\
\text { maximum purchase price, needed from oil value }\end{array}$ & & $\$ 1.13$ & $\$ 0.53$ & $/ \mathrm{kg}$ of seed \\
\hline Seed oil content & $14.7 \%$ & & & $\%$ of seed ${ }^{a}$ \\
\hline Seed required to obtain $1 \mathrm{~kg}$ of oil & 6.80 & & & $/ \mathrm{kg}$ of seed \\
\hline $\begin{array}{l}\text { Convert the seed price difference to an oil price } \\
\text { difference - divide by extracted oil \% of seed }\end{array}$ & & $\$ 7.71$ & $\$ 3.59$ & /kg of oil \\
\hline
\end{tabular}

a Sediment (oil and cake mix) was $4.9 \%$ of the seed weight.

In summary, results of the current study indicate that supplementing 10\% CPC in diets reduced feed intake, weight gain, final weight, carcass weight, and dressing percent of pigs, but did not affect feed efficiency or pork quality. Although the total yield of camelina and soybean in the relay-crop field was higher than camelina yield in the monocrop field, monocropping camelina is more economical than relay-planting with soybeans due to the difference in production costs. The viability of integrating camelina into organic pig production depends on marketing organic pigs for $\$ 2.4 \mathrm{~kg}^{-1}$ of live 
weight and marketing camelina oil for $\$ 3.59 \mathrm{~kg}^{-1}$ or more if monocropping.

\section{DATA AVAILABILITY STATEMENT}

The raw data supporting the conclusions of this article will be made available by the authors upon request, without undue reservation.

\section{ETHICS STATEMENT}

The protocol for the animal study was reviewed and approved by University of Minnesota Institutional Animal Care and Use Committee (IACUC\#: 2006-38189A).

\section{REFERENCES}

Almeida, F. N., Htoo, J. K., Thomson, J., and Stein, H. H. (2013). Amino acid digestibility in camelina products fed to growing pigs. Can. J. Anim. Sci. 93, 335-343. doi: 10.4141/cjas2012-134

AMS (2020). Midwest Regional Organic Grain and Feedstuffs Report. Washington, DC: Agricultural Marketing Service, USDA. Available online at: https://www. ams.usda.gov/mnreports/lsbmworganicgf.pdf (accessed July 10, 2021).

Amyot, L., McDowell, T., Martin, S. L., Renaud, J., Gruber, M. Y., and Hannoufa, A. (2019). Assessment of antinutritional compounds and chemotaxonomic relationships between Camelina sativa and its wild relatives. J. Agri. Food Chem. 67, 796-806. doi: 10.1021/acs.jafc.8b04 724

Berti, M. B., Gesch, R. W., Eynk, C., Anderson, J. V., and Cermak, S. (2016). Camelina uses, genetics, production and management. Ind. Crops Prod. 94, 690-710. doi: 10.1016/j.indcrop.2016.09.034

Boehlje, M. D., and Eidman, V. R. (1984). Farm Management. New York, NY: John Wiley and Sons.

Bowles, T. M., Mooshammer, M., ..., and Grandy, S. (2020). Long term evidence shows that crop-rotation diversification increases agricultural resilience to adverse growing conditions in North America. One Earth 2, 284-293. doi: 10.1016/j.oneear.2020.02.007

Canadian Food Inspection Agency (CFIA). (2011). CFIA-DD96-07: Determination of Environmental Safety of Monsanto Canada Inc.'s Roundup $®$ HerbicideTolerant Brassica napus Canola Line GT200. Ottawa, ON: Canadian Food Inspection Agency. Available online at: https://inspection.canada. $\mathrm{ca} /$ plant-varieties/plants-with-novel-traits/approved-under-review/ decision-documents/dd1996-07/dd96-07-supplement-/eng/1303837957812/ 1304976550984 (accessed July 20, 2021).

Dangol, N., Shrestha, D. S., and Duffield, J. A. (2020). Life-cycle energy, GHG and cost comparison of camelina-based biodiesel and biojet fuel. Biof 11, 399-407. doi: 10.1080/17597269.2017.1369632

Fan, L., and Eskin, N. A. M. (2013). Camelina oil: chemistry, properties and utilization. Recent Res. Devel. Lipids. 9, 125-137.

Fenwick, G. R., Griffiths, N. M., and Heaney, R. K. (1982). Bitterness in Brussels sprouts (Brassica oleracea L. var. gemmifera): the role of glucosinolates and their breakdown products. J. Sci. Food Agric. 34, 73-80. doi: 10.1002/jsfa.2740340111

Fruh, B., Bichicchio, D., Edwards, S., Hegelund, L., Leeb, C., Sundrum A., et al. (2014). Description of organic pig production in Europe. Org. Agri. 4, 83-92. doi: 10.1007/s13165-013-0056-9

Gesch, R. W., Archer, D. W., and Berti, B. T. (2014). Dual cropping winter camelina with soybean in the Northern Corn Belt. Agron. J. 106,1735-1745. doi: 10.2134/agronj14.0215

Gesch, R. W., and Cermak, S. (2011). Sowing date and tillage effects on fall-seeded camelina in the northern Corn Belt. Agron. J. 103, 980-987. doi: 10.2134/agronj2010.0485

\section{AUTHOR CONTRIBUTIONS}

YL and LJ designed the study. YL analyzed the data and prepared the manuscript. WL conducted economic analysis and helped to prepare the manuscript. CR and AH collected and summarized field data. RC collected meat quality data. FF, RG, and LJ helped to develop the experimental design, the methodology, and corrected the manuscript. All authors approved submission of this manuscript.

\section{FUNDING}

This work was supported by the Organic Transition Program (Award\# 2017-51106-27129) from the USDA National Institute of Food and Agriculture.

Gesch, R. W., and Johnson, J. M. F. (2015). Water use in camelina-soybean dual cropping systems. Agron. J. 107, 1098-1104. doi: 10.2134/agronj14.0626

Gesch, R. W., Matthees, H. L., Alvarez, A. L., and Gardner, R. D. (2018). Winter camelina: crop growth, seed yield, and quality response to cultivar and seeding rate. Crop Sci. 58, 2089-2098. doi: 10.2135/cropsci2018.01.0018

Harris, E. K., Mellencamp, M. A., Johnston, L. J., and Shurson, G. C. (2017). Growth performance of immunologically castrated pigs slaughtered at 5 , 7 , or 9 weeks after the second Improvest dose and fed diets containing corn dried distillers grains with solubles. J. Anim. Sci. 95, 806-819. doi: $10.2527 /$ jas.2016.0510

Hilbrands, A. H., Johnston, L. J., Cox, R. B., Forcella, F., Gesch, R. W., and Li, Y. Z. (2021). Effects of increasing dietary inclusion of camelina cake on growth performance of growing-finishing pigs. Transl. Anim. Sci. 5, 1-10. doi: $10.1093 /$ tas/txab140

Hoerning, C., Wells, M. S., Gesch, R., Forcella, F., and Wyse, D. L. (2020). Yield tradeoffs and weed suppression in a winter annual oilseed relay-cropping system. Agron. J. 112, 2485-2495. doi: 10.1002/agj2.20160

Johnson, J. M. F., Gesch, R. W., and Barbour, N. W. (2019). Spring camelina response to $\mathrm{N}$ rate: Balancing agronomics and environmental risk in the United States Corn Belt. Archiv. Agron. Soil Sci. 65, 640-653. doi: 10.1080/03650340.2018.1519803

Kahindi, R. K., Woyengo, T. A., Thacker, P. A., and Nyachoti, C. M. (2014). Energy and amino acid digestibility of camelina cake fed to growing pigs. Anim. Feed Sci. Tech. 193, 93-101. doi: 10.1016/j.anifeedsci.2014.03.012

Larson, B., Kliebenstein, J. B., and Honeyman, M. S. (2002). Comparison of Premiums and Returns in Organic Pork Production. Swine Research Report. Paper 16. Ames, IA: Iowa State Univ. Available online at: http://lib.dr.iastate. edu/swinereports_2001/16 (accessed July 20, 2021).

Larson, B., Kliebenstein, J. B., and Honeyman, M. S. (2003). Cost of Organic Pork Production. File B1-80. Ames, IA: Iowa State Univ.

Lazarus, W. F. (2020). Machinery Cost Estimates. Available online at: http:// wlazarus.cfans.umn.edu/william-f-lazarus-farm-machinery-management (accessed July 20, 2021).

Lee, J. W., Levesque, C. L., and Woyengo, T. A. (2017). Nutritive value of extruded cold-pressed camelina cake for pigs. J. Anim. Sci. 95, 126-127. doi: 10.2527/asasmw.2017.262

Liu, Y., Jaworski, N. W., Rojas, O. J., and Stein, H. H. (2016). Energy concentration and amino acid digestibility in high protein canola meal, conventional canola meal, and in soybean meal fed to growing pigs. Anim. Feed Sci. Tech. 212, 52-62. doi: 10.1016/j.anifeedsci.2015.11.017

Matthaus, B., and Zubr, J. (2000). Variability of specific components in Camelina sativa oilseed cakes. Ind. Crops Prod. 12, 9-18 doi: 10.1016/S0926-6690(99)00040-0

Meadus, W. J., Duff, P., McDonald, T., and Caine, W. R. (2014). Pigs fed camelina meal increase hepatic gene expression of cytochrome 8b1, aldehyde dehydrogenase, and thiosulfate transferase. J. Anim. Sci. Biotech. 5:1. doi: 10.1186/2049-1891-5-1 
National Organic Program (NOP). (2020). Agricultural Marketing Service, USDA. Available online at: Section A. Standards | Agricultural Marketing Service (usda.gov) (accessed July 20, 2021).

National Pork Producer Council (NPPC). (2000). Pork Composition and Quality Assessment Procedures. Des Monies, IA: National Pork Board.

National Research Council (NRC) (2012). Nutrient Requirements of Swine. 11th $E d n$. Washington, DC: National Academies Press.

Ní Eidhin, D., Burke, J., and O’Beirne, D. (2003). Oxidative stability of $\omega 3$-rich camelina oil and camelina oil-based spread compared with plant and fish oils and sunflower spread. J. Food Sci. 68, 345-353. doi: 10.1111/j.1365-2621.2003.tb14163.x

Ott, M. A., Eberle, C. A., Thom, M. D., Archer, D. W., Forcella, F., Gesch, R. W., et al. (2019). Economics and agronomics of relay-cropping pennycress and camelina with soybean in Minnesota. Agron. J. 111, 1281-1292. doi: 10.2134/agronj2018.04.0277

Pirvan, A. F., Jurcoane, S., and Matei, F. (2020). Life cycle assessment of Camelina sativa crop in a circular economy approach-a minireview. Sci. Bull. Biotech. 24, 189-193. Available online at: http://biotechnologyjournal.usamv.ro/pdf/ 2020/issue_2/Art26.pdf (accessed December 7, 2021).

Puzio, I., Grabos, D., Bienko, M., Radzki, R. P., Zowakiewics, A., and KosiorKorzecka, U. (2021). Camelina oil supplementation improves bone parameters in ovariectomized rats. Animals 11:1343. doi: 10.3390/ani11051343

Schieck, S. J., Shurson, G. C., Kerr, B. J., and Johnston, L. J. (2010). Evaluation of glycerol, a biodiesel coproduct, in grow-finish pig diets to support growth and pork quality. J. Anim. Sci. 88, 3927-3935. doi: 10.2527/jas.2010-2858

Smit, M. N., and Beltranena, E. (2017). Effects of feeding camelina cake to weaned pigs on safety, growth performance, and fatty acid composition of pork. J. Anim. Sci. 95, 2496-2508. doi: 10.2527/jas2016.1265

Tripathi, M. K., and Mishra, A. S. (2007). Glucosinolates in animal nutrition: a review. Anim. Feed Sci. Tech. 132, 1-27. doi: 10.1016/j.anifeedsci.2006.03.003

University of Minnesota Center for Farm Financial Management (CFFM) (2021). FINBIN Farm Financial Database. Available online at: http://www.finbin.umn. edu/ (accessed July 10, 2021).

USDA (2020). Certified Organic Livestock and Poultry Inventory and Sales: 2019. Available online at: https://www.usda.gov/media/blog/2020/10/28/organicthriving-agriculture-segment (accessed July 10, 2021).

van Doorn, H. E., van der Kruk, G. C., van holst, G. J., Raaijmakers-Ruijs, N., Postma, E., Groeneweg, H., et al. (1998). The glucosinolate sinigrin and progoitrin are the improtant determinants for taste preference and bitterness of mustard sprouts. J. Sci. Food Agric. 78, 30-38.

Villela, C. C. E. J., Cox, R. B., Shurson, G. C., Compart, K. M., Urriola, P. E., and Johnston, L. J. (2017). Effects of adding minimally refined cottonseed oil or crude glycerol to diets containing $40 \%$ corn distiller's dried grains with solubles on growth performance, carcass characteristics, and pork fat firmness of growing-finishing pigs. J. Anim. Sci. 95, 3057-3067. doi: 10.2527/jas.20 17.1383

Vollmann, J., Damboeck, A., Eckl, A., Schrems, H., and Ruckenbauer, P. (1996). "Improvement of Camelina sativa, an underexploited oilseed," in Progress in New Crops, ed J. Janick (Alexandria, VA: ASHS Press), 357-362.

Walia, M. K., Zanetti, F., Gesch, R. W., Krzyzaniak, M., Eynck, C., Puttick, D., et al. (2021). Winter camelina seed quality in different growing environments across Northern America and Europe. Ind. Crops Prod. 169:113639. doi: 10.1016/j.indcrop.2021.113639

Waraich, E. A., Ahmed, Z., Ahmad, R., Yasin Ashraf, M., Saifullah, N. V., Naeem, M. S., et al. (2013). Camelina sativa, a climate proof crop, has high nutritive value and multiple-uses: a review. Austr. J. Crop Sci. 7, 1551-1559. Available online at: https://www.researchgate.net/publication/ 286003757 (accessed December 7, 2021).

Weyers, S. L., Gesch, R. W., Forcella, F., Eberle, C. A., Thom, M. D., Matthees, H. L., et al. (2021). Surface Runoff and Nutrient Dynamics in Cover CropSoybean Systems in the Upper Midwest. J. Environ. Qual. 50, 158-171. doi: $10.1002 /$ jeq2.20135

Weyers, S. L., Thom, M. D., Forcella, F., Eberle, C. A., Matthees, H. L., Gesch, R. W., et al. (2019). Potential for nutrient loss reduction in winter oilseed cover cropped systems in the Upper Midwest. J. Environ. Quality. 48, 660-669. doi: $10.2134 /$ jeq2018.09.0350

Whitney, M. H., Shurson, G. C., Johnston, L. J., Wulf, D. M., and Shanks, B. C. (2006). Growth performance and carcass characteristics of grower-finisher pigs fed high-quality corn distillers dried grain with solubles originating from a modern Midwestern ethanol plant. J. Anim. Sci. 84, 3356-3363. doi: 10.2527/jas.2006-099

Woyengo, T. A., Beltranena, E., and Zijlstra, R. T. (2017). Effect of anti-nutritional factors of oilseed co-products on feed intake of pigs and pultry. Anim. Feed Sci. and Tech. 233, 76-86. doi: 10.1016/j.anifeedsci.2016.05.006

Woyengo, T. A., Patterson, R., and Levesque, C. L. (2018). Nutritive value of multienzyme supplemented cold-pressed camelina cake for pigs. J. Anim. Sci. 96, 1119-1129. doi: 10.1093/jas/skx025

Zhu, Y., Cox, R., Johnston, L. J., Reese, C., Forcella, F., Gesch, R. W., et al. (2021). Effects of increasing inclusion of camelina press-cake in diets fed to growing-finishing pigs on pork quality. Appl. Anim. Sci. 37, 357-366. doi: 10.15232/aas.2021-02161

Zubr, J. (1997). Oil-seed crop: Camelina sativa. Ind. Crop. Prod. 6, 113-119. doi: 10.1016/S0926-6690(96)00203-8

Conflict of Interest: The authors declare that the research was conducted in the absence of any commercial or financial relationships that could be construed as a potential conflict of interest.

Publisher's Note: All claims expressed in this article are solely those of the authors and do not necessarily represent those of their affiliated organizations, or those of the publisher, the editors and the reviewers. Any product that may be evaluated in this article, or claim that may be made by its manufacturer, is not guaranteed or endorsed by the publisher.

Copyright $\odot 2021$ Li, Lazarus, Reese, Hilbrands, Cox, Forcella, Gesch and Johnston. This is an open-access article distributed under the terms of the Creative Commons Attribution License (CC BY). The use, distribution or reproduction in other forums is permitted, provided the original author(s) and the copyright owner(s) are credited and that the original publication in this journal is cited, in accordance with accepted academic practice. No use, distribution or reproduction is permitted which does not comply with these terms. 